my publishers than of myself, that this opinion of his is not shared by the writer of any one, so far as I have seen, of the notices which have appeared in other papers.

Royal College of Science, London, June 19.

William A. Tilden.

\section{The Gravitation Constant}

I BEG to point out that at the end of the article on pp. I27128 of NATURE, relating to my researches on the gravitation constant, there is a misprint. The "oscillation "result for 1892 should be 5.523 instead of 5.520 .

The error is not great, but by correcting it a much better concordance appears between the four principal values.

Mariaschein in Bohemia, June 21. CHARles BraUN.

\section{THE AMERICAN EXCAVATIONS IN SOUTHERN BAB YLONIA.}

GOR the last fifteen or sixteen years we have been glad to watch the endeavours of the Americans to carry out systematic excavations in Southern Babylonia, and we feel sure that all will rejoice with them now that they are able to report a very considerable success. It will be remembered that the first American to visit that country with a view of acquiring antiquities was $\mathrm{Mr}$. Hayes Ward, who went out there early in the "eighties" and the report which he gave on the matter probably helped forward the later expeditions of Dr. Peters and Mr. Haynes. Dr. Peters and a small party of promising young men went to Baghdad in 1890 , and set out from that city for the ruins of Niffer, which are situated a few days' journey to the south-west, where they began to dig. For various reasons, however, Dr. Peters withdrew from the work soon afterwards, and the Committee of Excavations of Pennsylvania University determined to place the undertaking in the hands of Mr. Haynes, then the American Consul at Baghdad. Mr. Haynes took over the work, and for some years past he has devoted all his time to it, through the heats of summer when the land is burnt as hard as a brick, and through the rains of winter and early spring when the plains become seas of mud, has he lived at Niffer, patiently digging through the ruins of the temple, and tower, and ramparts, and courtyard, and hidden chambers of that ancient city. No other excavator has done his work so thoroughly, or so well in consequence, for he never left his post whilst diggings were going on; and though the cuneiform scholar sitting in a comfortable chair at home reading the descriptions of the work by Dr. Hilprecht ${ }^{\mathrm{I}}$ may think lightly of such devotion to science, it by no means diminishes its value. Moreover, the Arab of the neigh bourhood of Niffer is not the gentlest of men; on the contrary, when he is displeased with the "Frangi" excavator, he will break his water-jars, or slit his water-skins as they are passing on donkeys to the river, or try to burn down his tents, or even to kill hirn, as he has done to more than one excavator.

In the limited space at our disposal we do not intend to describe the details of Mr. Haynes' excavations, but only to call attention to the general results of his work and their bearings upon the early history of civilisation in the East. Like all the cities which lie between the Tigris and Euphrates below Hillah and Baghdad, the mounds of Niffer contain the ruins of a temple of considerable size and of a tower; both rested upon a solid clay platform, the intention of the architect being to lift the buildings which were to be set upon it out of the reach of floods and overflows of the river. Round these ran a wall more than fifty feet in thickness, the object of which was, naturally, to keep out foes from the temple

1 "The Pabylonian Expedition of the University of Pennsylvania," vol. i. 1893; vol. ii., 1896.: (Philadelphia: Reprinted from Trans. Amer. Philos Soc., N.S., vol. xviii., Nos. $x$ and 3. )

NO. 1444 , VOL. 56$]$ buildings and tower. The ruins which $\mathrm{Mr}$. Haynes found on the platform belong to the temple and tower which a king called Ur-gur built about 2600 B.C.; but below this, Mr. Haynes found another platform which Sargon I. had built some twelve hundred years earlier, for all the bricks bore the name of this king and of his son Naram-Sin. Digging down deeper, Mr. Haynes found the ruins of one or more temples, but there are no inscriptions or marks upon any object which will help us to date them. Elsewhere in the outlying buildings in the mound small but strongly built chambers were found, and it is thought that these were employed for the safe keeping of records, tablets, and the like. Thus it seems that the oldest inscribed object discovered at Niffer belongs to the reign of Sargon I., who, according to the information given on the famous Cylinder of Nabonidus, reigned 3200 years before that king's time. The question which will naturally be asked next is, "To what period do the temples, the ruins of which were found beneath Sargon's platform, belong? and who built them?" At present it is impossible to give a satisfactory answer. Those who would reckon years by the depth of deposits say these temple-ruins are about 2000 years older than Sargon's platform ; but this is, after all, only a guess, and if probabilities are taken into consideration we might as well date them at 10,000 B.C. as 6000 B.C., and we deprecate the use of exact figures in such matters. What is to be considered is the fact that about 3800 B.C. Sargon was able to build such a strong fortress, and that all the faculties of civilisation which such a power implied existed at that remote date. As to the earlier buildings which he found there and the platform on which they rested, they probably only stood upon the ruins of earlier buildings and of an earlier platform, and the site of Niffer being favourable for a city, it is more than likely that one stood there from time immemorial. To attempt to limit a civilisation of such antiquity as that of Southern Babylonia by thousands of years is, in our opinion, futile; though figures are useful at times to convey to the non-expert a general idea of antiquity. Mr. Haynes has proved that Niffer, in common with Tell-Lo, was one of a number of large and important cities which flourished in Southern Babylonia between 4000 B.C. and 2500 B.C., and the materials which he has obtained will enable us to describe the knowledge and religion, and manners and customs of its people with a fuiness and minuteness hitherto impossible. We trust that he will soon give us his own account of the work which he has carried out, and meanwhile accord him our thanks for what he has already done, and congratulations upon the great success which he has achieved.

\section{THE FRESH.WATER FAUNA OF LAKE TANGANYIKA.}

THE aquatic faunas of the great lakes of Central Africa, although like so many other features of the dark continent still largely unexplored, have attracted a good deal of attention during the last few years. It has been ascertained that some of these great sheets of water, although physiographically apparently so similar, are absolutely unlike each other in respect to the aquatic animals they contain. Thus the fishes and molluscs of Nyasa, which have been up to the present time by far the most completely known, show no forms which have deviated widely from easily recognisable freshwater stocks, or that suggest that Nyasa has at any past time been more directly connected with the sea. On the other hand, one of the first items of zoological information which reached Europe concerning Tanganyika, was the discovery of a Craspidote medusa by Boehm in I 893. The mere existence of fresh-water medusæ is such a rare and remarkable occurrence, that scientific interest 